\title{
BURNOUT IN ELITE TENNIS PLAYERS OF DIFFERENT JUNIOR CATEGORIES
}

\author{
BURNOUTEM TENISTAS DE ELITE EM DIFERENTES CATEGORIAS INFANTO-JUVENIS \\ BURNOUT EN TENISTAS DEÉLITE EN DIFERENTES CATEGORÍAS INFANTO-JUVENILES
}

Original Article

ARTIGO ORIGINAL

Artículo Original

Pedro de Orleans Casagrande ${ }^{1}$
(Physical Education Professional)
Danilo Reis Coimbra ${ }^{1}$
(Physical Education Professional)
Alexandro Andrade
(Physical Education Professional)

1. Universidade do Estado de Santa Catarina (UDESC), Centro de Ciências da Saúde e do Esporte (CEFID), Department of Physical Education, Laboratório de Psicologia do Esporte e do Exercício (LAPE), Florianopólis, SC, Brazil.

\section{Correspondence:}

Alexandro Andrade. Rua Pascoal Simone, 358, Coqueiros, Florianópolis, Santa Catarina, Brazil. 88080-350. alexandro.andrade.phd@gmail.com

\begin{abstract}
Introduction: Burnout syndrome manifests in athletes in the form of three main symptoms/characteristics: emotional and physical exhaustion, sport devaluation, and reduced sense of accomplishment. Faced with the need to achieve optimum performance, young tennis players are exposed to several stressors than can lead to burnout, yet few reports on burnout in tennis have been researched. Objective: The aim of this study was to analyze burnout in elite tennis players in different junior categories (CAT14, CAT16, CAT18). Methods: A total of 130 athletes, including 102 men $(\bar{x}=15.14 \pm 1.3)$ and 28 women $(\bar{x}=15.04 \pm 1.13)$, were selected for this cross-sectional study. Burnout was measured using a version of the Athlete Burnout Questionnaire (ABQ). Results: CAT18 tennis players had higher rates of overall burnout and sport devaluation compared with CAT16 and CAT14 players. CAT14 and CAT16 players had higher scores for "reduced sense of accomplishment," in association with sport devaluation. Conclusion: Differences found in CAT18 players may reflect the demands of transition from the junior to the professional circuit. Reduced sense of accomplishment should be monitored in athletes, to prevent burnout and cessation of sports activities. Level of Evidence III; retrospective comparative.
\end{abstract}

Keywords: Adolescent; Athlete; Sport; Racquet sports.

\section{RESUMO}

Introdução: A sindrome de burnout manifesta-se em atletas por meio de três principais sintomas/características: exaustão emocional e física, desvalorização esportiva e senso de realização reduzido. Diante da necessidade de obter um desempenho ideal, jovens tenistas estão expostos a fatores de estresse que podem levar ao burnout, porém poucos estudos sobre o burnout no tênis têm sido pesquisados. Objetivo: O objetivo deste estudo foi analisar o burnout em tenistas de elite em diferentes categorias infanto-juvenis (CAT14, CAT16, CAT18). Métodos: No total, 130 atletas, incluindo 102 homens $(\bar{x}=15,14 \pm 1,3)$ e 28 mulheres $(\bar{x}=15,04 \pm 1,13)$, foram selecionados para este estudo transversal. O burnout foi medido usando o Questionário de Burnout para Atletas (QBA). Resultados: Os tenistas da CAT18 apresentaram níveis mais altos de burnout geral e desvalorização esportiva com relação aos jogadores da CAT16 e CAT14. Os atletas da CAT14 e CAT16 apresentaram níveis mais altos de "senso de realização reduzido" em associação com a desvalorização esportiva. Conclusões: As diferenças encontradas nos atletas da CAT18 podem refletir as demandas de transição do circuito júnior para o profissional. A percepção de realização reduzida deve ser monitorada nos tenistas para evitar burnoute abandono das atividades esportivas. Nível de Evidência III; Estudo retrospectivo comparativo.

Descritores: Adolescente; Atletas; Esportes; Esportes com raquete.

\section{RESUMEN}

Introducción: El síndrome de burnout se manifiesta en atletas por medio de tres principales síntomas/ características: agotamiento emocional y físico, devaluación del deporte, y sentido de realización reducido. Ante la necesidad de obtener un rendimiento ideal, los jóvenes tenistas están expuestos a factores de estrés que pueden conducir al burnout, pero pocos estudios sobre el burnout en el tenis han sido investigados. Objetivo: El objetivo de este estudio fue analizar el burnout en tenistas competitivos de élite en diferentes categorías infanto-juveniles (CAT14, CAT16, CAT18). Métodos: En total, 130 atletas, incluyendo 102 hombres $(\bar{x}=15,14 \pm 1,3)$ y 28 mujeres $(\bar{x}=15,04 \pm 1,13)$, fueron seleccionados para este estudio transversal. El burnout fue medido usando el Cuestionario de Burnout para Atletas (CBA). Resultados: Los tenistas de la CAT18 presentaron niveles más altos de burnout general y devaluación deportiva con relación a los jugadores de la CAT16 y CAT14. Los jugadores de la CAT14 y CAT16 presentaron niveles más altos de "sentido de realización reducido" en asociación con la devaluación deportiva. Conclusiones: Las diferencias encontradas en los jugadores de la CAT18 pueden reflejar las demandas de transición del circuito júnior al profesional. La percepción de baja realización debe ser monitoreada en estos tenistas, para evitar burnout y abandono de las actividades deportivas. Nivel de Evidencia III; Estudio retrospectivo comparativo.

Descriptores: Adolescente; Atletas; Deportes; Deportes de raqueta. 


\section{INTRODUCTION}

Burnout syndrome is classically defined as psychological withdrawal from a previously enjoyable activity, with physical, emotional, and behavioral components, taking into account the interactions between environmental and personal characteristics. 'Burnout syndrome presents in athletes with three components: emotional and physical exhaustion, sport devaluation, and reduced sense of accomplishment. 2,3 Emotional and physical exhaustion is related to the demands of training and competition. Sport devaluation reflects a decrease in interest in and enjoyment of the sport. Reduced sense of accomplishment reflects dissatisfaction and frustration with performance and development in a sport. 2,3 $^{2}$

Scientific literature on Burnout in athletes is being published worldwide ${ }^{4}$, and theoretical model shave attempted to explain Burnout in sport ${ }^{1,3}$. However, Burnout remains a complex phenomenon, and can manifest in different ways in each athlete. Currently, Burnout is best understood through an integrated model. ${ }^{5}$

The literature shows that Burnout can occur in young athletes playing a variety of sports. ${ }^{6-8}$ Although first studied in tennis, ${ }^{9-11}$ few reports on Burnout in tennis have been published recently. ${ }^{12,13}$ In addition, larger-scale studies are needed in this population, as only one report evaluated more than 100 players. ${ }^{12}$

The process of training a tennis player involves years of involvement with the sport. This time is necessary for learning and development of a range of physical, technical, tactical, and psychological skills. ${ }^{14}$ Faced with the need to achieve optimum performance, young tennis players are exposed to several stressors than can lead to Burnout. The International Tennis Federation (ITF) Circuit includes the best junior players in the world, and tournament play is an important predictor of future success in professional tennis. ${ }^{15}$

Based on ITF criteria, youth tournaments are played in categories by age group. However, each category may have different stressors, based on training load, competition level, involvement, expectations, and goals. Although these stressors are associated with Burnout in tennis, ${ }^{9-13}$ no studies have compared the extent of Burnout in different junior tennis categories. It is important to investigate Burnout in these athletes, because some potential professional players may dropout of the sport due to Burnout. ${ }^{11,16}$

In addition, Burnout dimensions and the process of Burnout require greater understanding. Studies have demonstrated that emotional/ physical exhaustion, devaluation, and reduced sense of accomplishment can present with varying intensity, and can change during the course of a career. ${ }^{17}$

Therefore, this study aimed to analyze Burnout in elite tennis players in different junior categories and to examine Burnout dimensions in each category.

\section{METHODS}

A cross-sectional study was performed, using the database of the Brazilian Tennis Confederation, which ranked 1537 elite junior tennis players in categories 14, 16, and 18year olds in $2014 .^{18}$

Participants included 155 elite junior tennis players in two international competition categories, who were selected using a non-probabilistic method. The subjects were ranked by the South American Tennis Confederation (categories 14 and 16) and the ITF (category 18).

Of these155 players, 25 were excluded (16.13\%) because of errors in questionnaire completion. Therefore, the final sample consisted of 130 junior tennis players, with 102 men $(\bar{x}=15.14 \pm 1.3)$ and 28 women $(\bar{x}=15.04 \pm 1.13)$, accounting for $8.45 \%$ of all ranked junior tennis players, i.e., more than in other studies.
The taxonomy proposed by Swann, Moran, and Piggott ${ }^{19}$ was used to define the competitive level. This classification ranges from semi-elite to world-class elite, based on five criteria. This system was used to classify the elite junior tennis players.

At the sign in, researchers spoke with the athletes, and presented the objectives, instruments, and procedures of the study. The subjects completed the questionnaires individually. All procedures were monitored by experienced researchers. The average time for completion of a questionnaire was 20 min.

The present study used a questionnaire to obtain data about (a) participant gender and age, (b) history in the sport (dates of initiation and competition), and (c) training details (weekly load). The instrument is being used in recent studies in sports research. ${ }^{20-22}$

The study used a version of the Athlete Burnout Questionnaire ${ }^{3}$. The questionnaire consists of 15 items that correspond to factors related to Burnout. The athletes were questioned about perceptions related to current sports practice, and answers were given using a Likert scale rating, ranging from 1 (almost never) to 5 (almost always). The three subscales related to Burnout perception are "emotional/physical exhaustion", "devaluation", and "reduced sense of accomplishment".

Athlete rankings were obtained from the official website of the Brazilian Tennis Confederation. ${ }^{18}$

\section{Statistical analysis}

The analysis was performed using IBM SPSS version 20.0. The dates were analyzed using descriptive and inferential statistics. The Kolmogorov-Smirnov test was used to verify data normality.

Comparative tests were used to assess differences in Burnout between men and women tennis players, and between training variables. No significant differences were found ( $p>0.05$ ). Therefore, analysis was performed by combining sample data.

Based on ITF and Brazilian Tennis Confederation criteria, players were divided into three groups by age: 14 (CAT14), 16 (CAT16), and 18 (CAT18) years. Based on birth date, CAT14 included players aged 13 and 14 and CAT16 included players aged 15 and 16. CAT18 included players, aged 17 to 18, and it was considered a transitional category before professional player. The sample included 41 players (31.6\%) in CAT14, 64 (49.2\%) in CAT16, and 25 (19.2\%) in CAT18. There was no difference between the three categories ( $p>0.05)$ regarding training characteristics (initiation and competition) and weekly training load.

For inferential analysis, Burnout and dimensions were compared for the three categories using the Kruskal-Wallis test and post hoc MannWhitney test and Bonferroni correction. The effect size ( $r$ ) was calculated when comparisons resulted in significant differences ( $r=0.1$, small effect; $r=0.3$, moderate effect; $r=0.5$ large effect) in accordance with criteria established by Cohen ${ }^{23}$ for the social sciences and recommended for studies in sport psychology.

To compare Burnout dimensions between categories, the Friedman analysis of variance (ANOVA) test was performed, followed by the Wilcoxon post hoc test for CAT14 and CAT16. Repeated measures ANOVA, followed by post hoc paired t-tests, were used for CAT18. The delta $(\triangle)$ for the three categories was calculated and recorded for the between-category Burnout dimensions. The a significance level was 0.05 (95\%).

The present research was approved by the Committee of Ethics and Research in Human Beings of the State University of Santa Catarina (opinion: 988,292). All athletes were informed about all research procedures and signed the Terms of Assent form. The athletes answered the questionnaires individually in a reserved place. 


\section{RESULTS}

The competitive elite junior tennis players from CAT18 showed higher scores for Burnout in the three dimensions. "Reduced sense of accomplishment" was the most common dimension in all categories. The devaluation dimension showed lower scores in all categories (Table 1).

Significant differences were found in global Burnout $(p=0.001)$, "emotional/physical exhaustion" ( $p=0.025)$, "reduced sense of accomplishment" ( $p=0.000)$, and "devaluation" ( $p=0.006)$ among the three categories. Post hoc analysis was used to identify significant differences in global Burnout $(U=528.5, p=0.013, r=0.263, \triangle=0.35)$ and "devaluation" $(U=500.5, p=0.006, r=0.293, \Delta=0.44)$ between CAT16 and CAT18 players.

CAT18 players showed higher scores for global Burnout $(U=252.5$, $p=0.001, r=0.423, \Delta=0.51)$,"emotional/physical exhaustion" ( $U=319$, $p=0.010, r=0.316, \Delta=0.48)$, "reduced sense of accomplishment" $(U=237$, $p=0.000, r=0.450, \Delta=0.65)$, and "devaluation" $(U=286, p=0.002 ; r=0.423$, $\Delta=0.48)$, when compared with CAT16 players.

CAT16 players showed higher scores for "reduced sense of accomplishment" $(U=813.5, p=0.001, r=0.321, \Delta=0.39)$, when compared with CAT14 players. Thus, CAT18 players showed higher scores for global Burnout," reduced sense of accomplishment,"'emotional/physical exhaustion," and "devaluation" when compared with CAT16 and CAT14 players. These differences are shown in Figure 1.

Figure 2 shows differences between Burnout dimensions in tennis players from each category. There were significant differences in all categories. Players from CAT14 had higher scores for"reduced sense of accomplishment"than for "devaluation" $(z=-2.503, p=0.012, r=0.390, \Delta=0.30)$. In addition, CAT18 players had higher scores for "reduced sense of accomplishment"than for "devaluation"( $z=2.910, p=0.008, r=0.510, \Delta=0.47)$. CAT16 players showed significant differences in scores for "reduced

Table 1. Global Burnout and Burnout dimensions among competitive elite junior tennis players of CAT14, CAT16 and CAT18 (mean, standard deviation and median).

\begin{tabular}{|c|c|c|c|c|c|c|c|c|c|c|c|c|}
\hline \multirow{3}{*}{ Category } & & & & \multicolumn{9}{|c|}{ Burnout dimensions } \\
\hline & \multicolumn{3}{|c|}{ Global Burnout } & \multicolumn{3}{|c|}{$\begin{array}{l}\text { Emotional/ } \\
\text { Physical } \\
\text { exhaustion }\end{array}$} & \multicolumn{3}{|c|}{ Devaluation } & \multicolumn{3}{|c|}{$\begin{array}{l}\text { Reduced sense } \\
\text { of } \\
\text { accomplishment }\end{array}$} \\
\hline & $\bar{x}$ & \pm & Med & & \pm & Med & $\overline{\mathbf{x}}$ & \pm & Med & $\overline{\mathbf{x}}$ & \pm & Med \\
\hline CAT14 & 1.82 & 0.61 & 1.66 & 1.83 & 0.98 & 1.40 & 1.53 & 0.70 & 1.40 & 1.83 & 0.59 & 1.80 \\
\hline CAT16 & 1.98 & 0.54 & 1.90 & 1.93 & 0.76 & 1.80 & 1.57 & 0.64 & 1.40 & 2.22 & 0.64 & 2.20 \\
\hline CAT18 & 2.33 & 0.62 & 2.33 & 2.31 & 0.83 & 2.20 & 2.01 & 0.79 & 2.00 & 2.48 & 0.68 & 2.60 \\
\hline
\end{tabular}

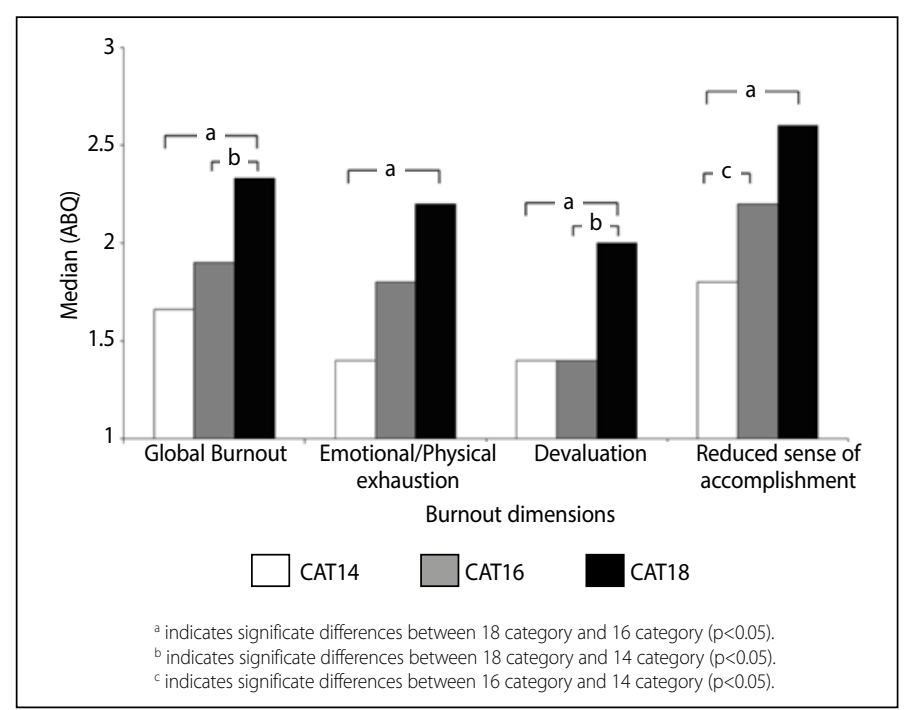

Figure 1. Global Burnout and Burnout dimensions among competitive elite junior tennis players of CAT14, CAT16 and CAT18.

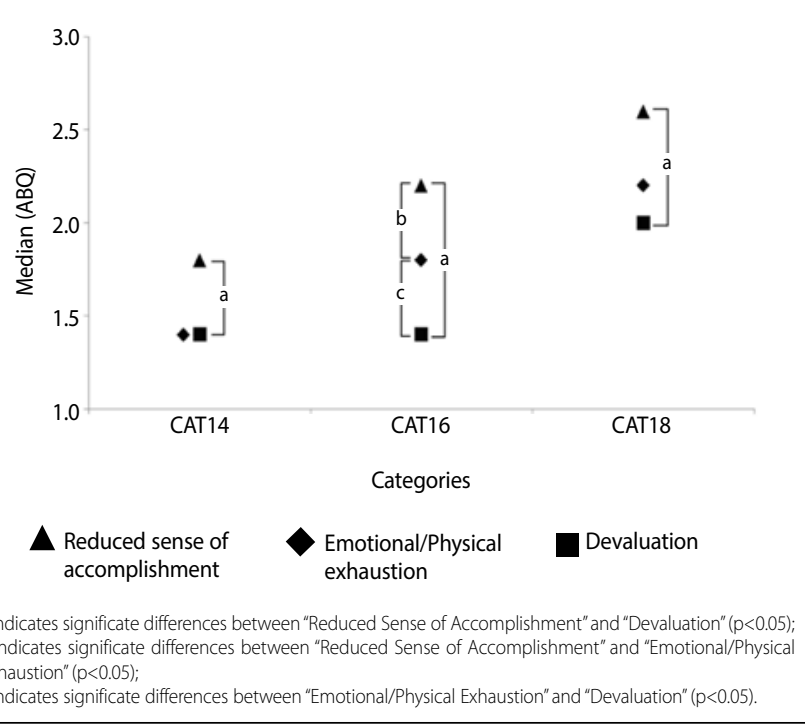

Figure 2. Differences in Burnout dimensions in competitive elite junior tennis players of CAT14, CAT16 and CAT18.

sense of accomplishment" and "devaluation" ( $z=-5.927, p=0.000, r=0.740$, $\Delta=0.65)$. However, CAT16 players also showed differences in scores for "reduced sense of accomplishment" and "emotional/physical exhaustion" ( $z=-2.826, p=0.005, r=0.290, \Delta=0.29$ ). In addition, there were differences in scores for "emotional/physical exhaustion" and "devaluation" (z=-3.768, $p=0.000 ; r=0.470 ; \Delta=0.30$ ).

\section{DISCUSSION}

This is the first reported analysis of Burnout in competitive elite tennis players of different categories. This report also compared scores for Burnout dimensions in each category.

\section{Higher scores for global Burnout and devaluation in CAT18 players}

This study showed higher scores for global Burnout and devaluation in CAT18 players, when compared with CAT16 players. Important differences were found in scores for global Burnout and the three dimensions in a comparison between CAT18 and CAT14 players. These differences may reflect requirements for transition from youth player to professional status. In pursuit of initial rankings on the professional circuit, CAT18 players must meet several demands, with participation in professional tournaments, more and longer trips, increased commitment, and dual career management. In tennis, competition at the highest level is essential for a successful career ${ }^{24}$. Furthermore, performance in this category is an important indicator of later success in tennis. ${ }^{25}$

Devaluation may be related to decreased motivation and interest in the sport. ${ }^{3}$ Therefore, differences found in the levels of sports devaluation in CAT18 athletes may reflect not only changes in the competitive environment, but also a decision period for the athlete, as to whether or not to pursue a professional career. An increase in devaluation may also reduce performance, because of loss of motivation, and the athlete may need time to reassess goals or season objectives. In fact, studies among burned out tennis players report changes in priorities, and athletes may have less concern with performance in competition and training. ${ }^{4,10}$ Although these players do not have critical devaluation scores, there is insufficient knowledge of the Burnout process, and not all young athletes who drop out have Burnout. For example, athletes may withdraw voluntarily or because of injury ${ }^{26}$. However, those who drop out due to Burnout may have negative perceptions about the sport even years later, and may even avoid playing for recreation and health. ${ }^{11,16}$ 
CAT14 players showed lower scores for global Burnout and all dimensions. This may be because players in this category do not engage exclusively in one sport. Evidence suggests that at this stage it is important to diversify sports practice, because early specialization does not lead to long-term success in the sport, and may increase the risk of injury and Burnout ${ }^{26}$. Youth athletes should delay specializing in a single sport until after this stage, to obtain experience through diversification and practice, which are important for development of motivation and perceived competence. ${ }^{27}$

\section{Higher scores for reduced sense of accomplishment in CAT16 players than in CAT14 players}

Higher scores for reduced sense of accomplishment in CAT16 players may reflect increased time and dedication linked to unrealistic expectations, resulting in perceived lack of progress in skills or advancement. Furthermore, there is a requirement for technical, tactical, and physical performance beyond the level of biological and emotional maturation ${ }^{26}$, making this category more difficult. To prevent this perception, the development of coping strategies is recommended, with social support (coach and parents) and appropriate goal setting. ${ }^{27,28}$

\section{Differences in Burnout dimension scores in the three categories}

"Devaluation" showed the lowest score in the three categories. This result is similar to that in other studies of young athletes. ${ }^{6-8}$ However, all categories showed highest scores for reduced sense of accomplishment, unlike the results in other studies, in which athletes showed the highest scores for emotional/physical exhaustion associated with practice time ${ }^{13}$ or the end of the season. ${ }^{17}$ However, this study did not find high scores for "emotional/physical exhaustion".

Comparisons between the three Burnout dimensions require further studies and greater understanding of their characteristics and correlations. Previous studies ${ }^{16}$ found that devaluation occurs after a period of reduced sense of accomplishment in junior tennis players. Moreover, previous studies 29,30 indicate that the dimensions emerge at different times, suggesting that devaluation is the final step, after a period of reduced sense of accomplishment and emotional/physical exhaustion.

Furthermore, Burnout can arise for different reasons. Previous studies ${ }^{5}$ proposed an integrated model to explain Burnout in sports. The need for evaluation of causative factors, warning signs, and consequences associated with the athlete's personality, as well as coping strategies and the sports environment, was emphasized.

Because of the cross-sectional design, we could not determine when Burnout develops and which dimension presents first. However, the study highlights the relevance of evaluation of tennis players, as only a single report investigated more than 100 junior players. ${ }^{12}$ Moreover, this was the first in-depth report about Burnout dimensions in junior tennis players.

\section{CONCLUSION}

Competitive elite junior tennis players of different categories showed differences in Burnout dimensions. The CAT18 players had higher scores for global Burnout and devaluation than CAT16 and CAT14 players. CAT16 players had higher scores for reduced sense of accomplishment CAT14 players. Reduced sense of accomplishment scores was higher in players in all three categories. Future research with a longitudinal design to evaluate Burnout among junior tennis players must be performed to verify when Burnout and dimensions begin to emerge, to enable greater understanding of the process.

Finally, understanding of Burnout and its dimensions in junior tennis players is crucial to improving the quality of their athletic development and physical and mental health. Athletes should be monitored to prevent Burnout and withdrawal from sports.

All authors declare no potential conflict of interest related to this article.

AUTHORS' CONTRIBUTIONS: Each author made significant individual contributions to this manuscript. AA (0000-0002-6640-9314)*: was responsible for conception of the text, participated actively in the discussion of results, and was responsible for the critical writing of the intellectual content, review and approval of the final version of the article. POC (0000-0001-8456-9111)*: contributed actively to the writing of the manuscript and the data collection, analysis and interpretation of results, and participated actively in the discussion of results. DRC (0000-0002-6055-0667)*: assisted in data collection, analysis and interpretation of results, and participated actively in the discussion of results. *ORCID (Open Researcher and Contributor ID).

\section{REFERENCES}

1. Smith RE. Toward a cognitive-affective model of athletic burnout. Journal of sport psychology. 1986;8(1):36-50.

2. Raedeke T. Is athlete burnout more than Just stress? A sport commitment perspective. J Sport Exerc Psychol. 1997;19(4):396-417

3. Raedeke TD, Smith AL. Development and preliminary validation of an athlete burnout measure. J Sport Exerc Psychol. 2001;23(4):281-306.

4. Goodger K, Gorely T, Lavallee D, et al. Burnout in sport: A systematic review. Sport Psychol. 2007;21 (2):127-51.

5. Gustafsson H, Kenttä G, Hassmén P. Athlete burnout: An integrated model and future research directions. Int Rev Sport Exerc. Psychol. 2011;4(1):3-24.

6. Appleton PR, Hall HK and Hill AP. Relations between multidimensional perfectionism and burnout in junior-elite male athletes. Psychol Sport Exerc. 2009;10(4): 457-65

7. Curran T, Appleton PR, Hill AP, et al. Passion and burnout in elite junior soccer players: The mediating role of self-determined motivation. Psychol Sport Exerc. 2011;12(6):655-61.

8. Isoard-Gautheur S, Guillet-Descas E and Lemyre PN. A prospective study of the influence of perceived coaching style on burnout propensity in high level young athletes: using a self-determination theory perspective. Sport Psychol. 2012;26:282-98.

9. Gould D, Udry E, Tuffey S, et al. Burnout in competitive junior tennis players: I. A quantitative psychological assessment. Sport Psychol. 1996;10:322-40.

10. Gould D, Tuffey S, Udry E, et al. Burnout in competitive junior tennis players: III. Individual differences in the burnout experience. Sport Psychol. 1997;11(3):257-76.

11. Gould D, Tuffey S, Udry E, et al. Burnout in competitive junior tennis players II: qualitative content analysis and case studies. Sport Psycho Champaign. 1996;10(4):341-66.

12. Balaguer I, Duda JL, Moreno Y, et al. Interplays between situational and dispositional goals perspectives and psychological burnout. Acciónpsicológica. 2009;6(2):63-75.

13. Casagrande PO, Andrade A, Viana MS, Vasconcelos DIC. Burnout in Brazilian junior tennis players. Motricidade. 2014;10(2):60-71.

14. Fett J, Ulbricht Wiewelhove T. et al. Athletic performance, training characteristics, and orthopedic indications in junior tennis Davis Cup players. Int J Sports Sci Coach. 2017;12(1):119-29.

15. Reid M, Crespo M, Santili L. The ITF junior boys circuit and its role in professional player development. ITF Coaching and Sport Science Review. 2005;35(23).
16. Goodger K, Wolfenden L and Lavallee D. Symptoms and consequences associated with three dimensions of burnout in junior tennis players. Int J Sport Psychol. 2007;38(4):342-64.

17. Cresswell SL, Eklund RC. Changes in athlete burnout over a thirty-week "rugby year". J Sci Med Sport 2006;9(1-2):125-34

18. CBT. Confederação Brasileira de Tênis. 2014 [acesso 2015 mar 16] <http://www.tenisintegrado.com.br/> 19. Swann C, Moran A, Piggott D. Defining elite athletes: Issues in the study of expert performance in sport psychology. Psychol Sport Exerc. 2015;16: 3-14.

20. Andrade A, Bevilacqua GG, Coimbra DR,Pereira FS, Brandt R al. Sleep quality, mood and performance: a study of Elite Brazilian Volleyball Athletes. J Sports Sci Med. 2016;15(4):601-5.

21. Brandt R, Bevilacqua G, Andrade A. Perceived sleep quality, mood states, and their relationship with performance among Brazilian elite athletes during a competitive period. J Strength Cond Res. 2017;31(4):1033-9.

22. Brandt R, Liz CM, Crocetta, et al. Mental health and associated factors in athletes during the open games of Santa Catarina. Rev Bras Med Esporte. 2014;20:276-80.

23. CohenJ. Statistical power analysis for the behavioral science. 2 edn edition. Hillsdale: Erlbau, 1988

24. Brouwers J, Sotiriadou P, Bossche JD. Sport-specific policies and factors that influence international success: the case of tennis. Sport Management Review. 2014;18(3): 343-58.

25. Brouwers J, De BosscherV. and Sotiriadou P. An examination of the importance of performances in youth and junior competition as an indicator of later success in tennis. Sport Management Review. 2012; 15(4):461-75.

26. Stambulova N, Alfermann D, Statler T, et al. ISSP Position Stand: Career Development and Transitions of Athletes. Career Development and Transitions. 2009;7:395-412.

27. DiFiori JP, Benjamin HJ, Brenner JS, Gregory A, Jayanthi N, Landry GL, et al. Injuries and burnout in youth sports: a position statement from the American Medical Society for Sports Medicine. $\mathrm{Br}$ J Sports Med. 2014;48(4):287-8.

28. Côté J. and Vierimaa M. The developmental model of sport participation: 15 years after its first conceptualization. Sci Sports. 2014; 29:63-69.

29. Gustafsson H, Hassmén P, Kenttä G, et al. A qualitative analysis of burnout in elite Swedish athletes. Psychol Sport Exerc. 2008;9(6): 800-16

30. Cresswell SL, Eklund RC. Athlete Burnout: A longitudinal Qualitative Study. Sport Psychol. 2007;21(1):1-20 